\title{
STRATEGI DALAM MENINGKATKAN KOMPETENSI DAN PROFESIONALISME PUSTAKAWAN \\ DALAM MENGOPTIMALKAN KEMBALI REFERENCE SERVICE TERHADAP PEMUSTAKA DI PERPUSTAKAAN UNIVERSITAS NEGERI PADANG
}

\author{
Falian Sumitra \\ Program Studi Perpustakaan dan Ilmu Informasi, Fakultas Bahasa dan Seni, Universitas Negeri Padang \\ Falians040@gmail.com
}

\begin{abstract}
The reference service at the library is currently less than optimal. Therefore, several strategies are needed to improve the competence and professionalism of librarians in reference services. One of the reference services that still needs optimization in improving the competence of librarians is the Padang State University Library. The method used in this article is a qualitative method with a descriptive approach. This type of research in writing this article uses the Research Library method which means a literature or literature study. The purpose of this research is to find out the strategies used by libraries to improve the competence and professionalism of librarians in reference services and to find out what the obstacles are in the Padang State University Library.
\end{abstract}

Keywords: Reference Services; competence; professionalism

\section{PENDAHULUAN}

Perpustakaan menurut (Pendit, 2009) merupakan suatu institusi yang terus mengalami perubahan, adaptif dengan perkembangan teknologi, kendati relatif tak mengalami banyak perubahan tradisi aktivitas pokoknya sebagai penghimpun,penyimpan, serta penyedia rekaman pengetahuan. Selain itu, perpustakaan merupakan gedung yang berisikan informasi yang dibutuhkan pemustaka seperti buku, jurnal, peta, buku panduan, petunjuk khusus, kumpulan indeks, kumpulan abstrak, dll. Koleksi tersebut dapat dipinjam atau dibaca ditempat oleh pemustaka.

Adapun koleksi-koleksi tersebut terdapat di berbagai perpustakaan misalnya di perpustakaan perguruan tinggi. Koleksi tersebut sangat bermafaat bagi pustakawan untuk memenuhi kebutuhan informasi dari pemustaka.

Perpustakaan perguruan tinggi merupakan sebuah sarana penunjang yang didirikan untuk mendukung kegiatan Civitas Akademik, dimana 
Published by Program Studi Perpustakaan dan Ilmu Informasi FBS Universitas Negeri Padang, Indonesia

perguruan tinggi itu berada.

Perpustakaan perguruan tinggi adalah perpustakaan yang tergabung dalam lingkungan lembaga pendidikan tinggi, baik berupa perpustakaan universitas, perpustakaan fakultas, perpustakaan akademik, dan perpustakaan sekolah tinggi (Berawi, 2012). Perpustakaan perguruan tinggi haruslah memiliki pustakawan yang kompeten dan profesional dalam melakukan pemenuhan kebutuhan akan informasi dari pemustaka.

Pustakawan di perpustakaan perguruan tinggi merupakan seseorang yang memiliki kompetensi dan profesionalisme dalam bekerja. Dalam artian lain pustakawan menurut Poerwadarminta dalam (Azis, 2006) menambahkan bahwa, "Pustakawan adalah ahli perpustakaan. Dengan pengertian tersebut berarti pustakawan sebagai tenaga yang berkompeten dibidang perpustakaan, dokumentasi, dan informasi. Artinya, seorang pustakawan harus memberikan layanan kepada pemustaka dengan profesional dan maksimal untuk memenuhi kebutuhan akan informasi dari pemustaka.

Layanan di perpustakaan harus bersifat universal, artinya berlaku secara umum atau untuk keseluruhan bagi siapa saja yang membutuhkannya. Jadi, pelayanan yang diberikan oleh pustakawan harus maksimal agar kebutuhan informasi pemustaka terpenuhi dan perpustakaan tetap eksis.

Dalam hal pemenuhan informasi pemustaka, koleksi-koleksi yang tersedia di perpustakaan masih kurang dalam pemenuhan informasi dari pemustaka. Oleh karena itu, di sebuah perpustakaan seharusnya ada layanan yang bertujuan untuk menjawab segala pertanyaan atas kebutuhan informasi yang dibutuhkan pemustaka sehingga terpenuhinya kebutuhan informasi pemustaka lalu pemustaka merasa puas dengan jawaban dari pustakawan yang diberikan kepada pemustaka. Layanan yang dimaksud adalah layanan referensi. Menurut Louis Shores pelayanan referensi adalah bagian dari pelayanan perpustakaan yang tugasnya menginterprestasikan seluruh koleksi 
Published by Program Studi Perpustakaan dan Ilmu Informasi FBS Universitas Negeri Padang, Indonesia

perpustakaan untuk kepentingan pemakainya (Kalsum, 2016). Layanan referensi sebaiknya dikelola oleh seorang pustakawan yang memiliki kompetensi dan profesionalisme dalam melayani pemustaka.

Kompetensi menurut Saleh (2004;2), "Kompetensi sebagai pengetahuan, dan ketrampilan yang dituntut untuk melaksanakan dan atau menunjang pelaksanaan pekerjaan, yang merupakan dasar bagi penciptaan nilai dalam suatu organisasi" (Siregar, 2015).

Profesionalisme

menurut Siagian $(2009 ; 163)$ professionalisme adalah keandalan dalam pelaksanaan tugas sehingga telaksana dengan mutu yang baik, waktu yang tepat, cermat dan dengan prosedur yang mudah dipahami dan diikuti oleh pelanggan atau masyarakat (Siagian, 2009).

Idealnya pustakawan harusnya handal didalam layanan referensi dan mampu memenuhi kebutuhan informasi pengguna. Pustakawan yang ada dilayanan ini seharusnya kompeten dan profesional dalam memenuhi kebutuhan informasi dari pemustaka.
Namun, di perpustakaan yang saya lihat layanan ini sangat sepi pemustaka dan bahkan pustakawan yang berjaga dilayanan tersebut bisa dibilang tidak ahli dalam layanan referensi tersebut. Berdasarkan hal tersebut dapat saya rumusukan beberapa masalah yaitu, (1) strategi perpustakaan dalam meningkatkan kompetensi dan profesionalisme pustakawan dalam mengoptimalkan layanan referensi di Perpustakaan Universitas Negeri Padang, (2) kendala yang dihadapi oleh perpustakaan dalam meningkatkan kompetensi dan profesionalisme pustakawan di Perpustakaan Universitas Negeri Padang.

Oleh karena itu, saya selaku penulis tertarik untuk meneliti tentang layanan referensi di Perpustakaan Universitas Negeri Padang. Hal yang saya teliti yaitu dengan judul "Strategi Dalam Meningkatkan Kompetensi dan Profesionalisme Pustakawan Dalam Mengoptimalkan Kembali Reference Service Terhadap Pemustaka Di Perpustakaan Universitas Negeri Padang". 
Published by Program Studi Perpustakaan dan Ilmu Informasi

\section{METODE}

Menurut Arikunto

(Cahyaningtyas \& Iriyani, 2015) metode penelitian adalah cara yang digunakan oleh peneliti dalam pengumpulan data penelitiannya. Berdasarkan pengertian tersebut dapat disimpulkan bahwa metode penelitian adalah cara yang digunakan oleh peneliti untuk mengumpulkan data yang diperlukan dalam penelitiannya. Metode yang digunakan dalam artikel ini adalah metode kualitatif.

Menurut Sugiyono (Sugiyono, 2016) metode penelitian kuantitatif dapat diartikan sebagai metode penelitian yang berandaskan pada filsafat positivisme, digunakan untuk meneliti populasi atau sampel tertentu, teknik pengambillan sampel umunya diambil secara random, pengumpulan data menggunakan instrumen penelitian, analisis data bersifat kuantitatif atau statistis dengan tujuan menguji hipotesis yang telah ditetapkan.

Teknik pengumpulan data dalam artikel ini adalah (1) penelitian pustaka, (2) observasi, dan mengakses situs internet. Sumber data yang digunakan dalam artikel ini adalah data primer dan sekunder. Data primer berupa hasil observasi dan data sekunder berupa buku-buku, jurnal, majalah dan artikel yang relevan dengan permasalahan mengenai bagaimana strategi meningkatkan profesionalisme pustakawan dalam mengoptimalkan Reference Service kepada pemustaka di perpustakaan agar kebutuhan informasi pemustaka terpenuhi.

HASIL DAN PEMBAHASAN Strategi perpustakaan dalam meningkatkan kompetensi dan profesionalisme pustakawan

\section{Menggunakan media SMS}

Penggunaan SMS pada saat ini merupakan suatu hal yang ketinggalan zaman pada zaman modern saat ini. Namun, media SMS ini sangat cocok digunakan bagi pustakawan di layanan referensi karena akan membantu pustakawan dengan mudah berkomunikasi dengan pemustaka yang tidak dapat berkunjung langsung ke perpustakaan. Selain itu, media SMS ini 
Published by Program Studi Perpustakaan dan Ilmu Informasi FBS Universitas Negeri Padang, Indonesia

juga dapat meningkatkan kompetensi dan profesionalisme seorang pustakawan dalam mencari dan menemukan berbagai literatur yang dibutuhkan oleh pemustaka dalam jangka waktu yang ditentukan, jumlah literatur yang dibutuhkan dan jenis literatur yang dibutuhkan oleh pemustaka sehingga informasi yang dibutuhkan oleh pemustaka terpenuhi.

\section{Menggunakan media sosial}

Penggunaan facebook dan instagram sangat bermanfaat dan dapat dengan mudah mengembangkan kompetensi seorang pustakawan di layanan referensi. Hal ini dapat menjadikan seorang pemustaka tertarik dengan jasa yang ditawarkan oleh pustakawan layanan referensi melalui media sosial yang tersedia sehingga pemustaka dapat dengan mudah menghubungi pustakawan tersebut dan dan berkomunikasi melalui media sosial tersebut sehingga informasi yang dibutuhkan oleh pemustaka terpenuhi. Selain itu, penggunaan media sosial ini juga dapat mengembangkan keterampilan seorang pustakawan dalam mendesain brosur ataupun pamflet yang menarik dan menyusun kata-kata dalam sebuah postingan sehingga pemustaka tertarik untuk menggunakan jasa yang ditawarkan oleh pustakawan dan dapat membuat perpustakaan menjadi lebih eksis di zaman modern saat ini.

Penggunaan twitter bagi perpustakaan yaitu seorang kepala pustakawan dapat memberikan informasi terbaru terkait perpustakaannya, seperti penambahan koleksi baru, jadwal kegiatan yang akan dilakukan perpustakaan dalam sepekan, informasi terkait penambahan fasilitas di perpustakaan, dan lain-lain. Informasi ini akan bermanfaat dan membuat seluruh pustakawan yang ada di perpustakaan tersebut update dan tidak ketinggalan informasi tentang perpustakaannya.

\section{Membangun komunikasi yang baik}

Pustakawan sebagai seorang pelayan jasa informasi dapat berkomunikasi kepada pemustaka dengan baik karena dengan pemustaka bersikap ramah dan dengan senang hati 
Published by Program Studi Perpustakaan dan Ilmu Informasi

menanyakan kebutuhan akan informasi dari pemustakan maka pemustaka akan merasa senang sehingga terjalin sebuah komunikasi yang baik.

Menurut (Effendy, 1993) komunikasi yang baik yaitu "Komunikasi tidak hanya informatif, yakni agar orang lain mengerti dan tahu, tetapi tidak juga persuasif, yakni agar orang lain bersedia menerima suatu paham atau keyakinan melakukan suatu perbuatan atau kegiatan dan lainlain".

Penjelasan diatas menunjukkan bahwa komunikasi tidak hanya suatu kegiatan untuk mentransfer sebuah informasi melainkan merupakan cara yang dilakukan oleh pustakawan ketika melayani pemustaka agar pemustaka merasa terlayani dan dihargai sebagai makhluk sosial. Oleh karena itu pustakawan sebaiknya harus mengenal lebih dalam bagaimana karakter dan watak dari pemustaka yang dilayaninya agar pustakawan dapat memahami informasi apa yang dibutuhkan oleh pemustaka tersebut sehingga kebutuhan akan informasi pemustaka terpenuhi dan pemustaka merasa puas dengan pelayanan yang diberikan oleh pustakawan.

kendala yang dihadapi oleh perpustakaan dalam meningkatkan kompetensi dan profesionalisme pustakawan

1. Kurangnya sarana dan prasarana diruangan layanan referensi

Sarana yang terdapat di suatu ruangan dapat menjadi kendala dalam pengembangan kompetensi dan profesionalisme pustakawan. Sarana yang kurang yaitu seperti AC yang tidak dingin sehingga membuat ruangan tersebut menjadi terasa panas dan membuat pemustaka yang berkunjung menjadi tidak nyaman dan tidak betah.

Rak koleksi yang sudah lapuk akan membuat koleksi yang tersusun akan terlihat seperti koleksi yang usang dan tidak terawat serta akan membuat pemustaka yang berkunjung tidak nyaman ketika berada diruangan tersebut.

Oleh karena itu sarana yang bagus akan membantu meningkatkan kompetensi dan profesionalisme seorang 
Published by Program Studi Perpustakaan dan Ilmu Informasi FBS Universitas Negeri Padang, Indonesia

pustakawan karena dengan sarana dan prasarana yang baik dan memadai maka pemustaka akan betah berada di ruangan tersebut dan pustakawan dapat mengimplementasikan keterampilannya kepada pemustaka yang berkunjung.

\section{Kurangnya sumber daya manusia}

Kurangnya sumber daya manusia juga menjadi hambatan bagi peningkatan kompetensi dan profesionalisme seorang pustakawan karena apabila seorang pustakawan yang bertugas di layanan referensi merupakan orang yang tidak memiliki latar belakang ilmu perpustakaan maka dia akan membutuhkan waktu yang lama untuk menemukana bahan pustaka yang dibutuhkan sedangkan pemustaka membutuhkan seorang pustakawan ahli dibidang tersebut untuk menemukan bahan pustaka dalam waktu yang singkat.

\section{Etika pemustaka yang berkunjung} ke perpustakaan

Sulit bagi pemustaka untuk menyampaikan atau menanyakan sesuatu kepada pustakawan tentang informasi yang dibutuhkannya. Hal ini disebabkan karena pemustaka masih ada rasa takut, cemas, segan, ataupun pemustaka yang malas untuk bertanya. Dalam kasus seperti ini jadi sebaiknya pustakawan harus sigap dan membaca gerak gerik dari pemustaka dan mengunjungi pemustaka tersebut lalu menanyakan tentang informasi apa yang dibutuhkan olehnya.

\section{PENUTUP}

\section{Simpulan}

beberapa strategi tersebut dapat memudahkan pustakawan dalam menemukan sumber informasi yang dibutuhkan.

pengunaan media SMS dan media sosial akan membantu untuk meningkatkan kompetensi dan profesionalisme pustakawan di layanan referensi karena dengan adanya media ini pustakawan di layanan referensi akan belajar untuk menggunakan teknologi tersebut dengan benar sehingga mumpuni dalam menggunakannya dan dapat memenuhi 
kebutuhan informasi pemustaka di zaman modern saat ini. Selain itu komunikasi yang baik juga sangat penting bagi seorang pustakawan di layanan referensi karena pustakawan di layanan referensi harus bersikap ramah dan pustakawan harus bisa memahami karakter dari pemustakanya agar informasi yang dibutuhkan pemustaka terpenuhi.

$\begin{array}{rcr}\text { Selain } & \text { strategi } & \text { yang } \\ \text { memudahkan } & \text { pustakawan } & \text { dalam } \\ \text { menemukan } & \text { informasi } & \text { yang }\end{array}$
dibutuhkan pemustaka juga terdapat beberapa kendala diantaranya kurangnya sarana dan prasarana di layanan referensi, kurangnya sumber daya manusia, dan etika pemustaka yang berkunjung ke perpustakaan.

\section{Saran}

Berdasarkan kesimpulan yang menjelaskan bahwa adanya kendala dalam meningkatkan kompetensi pustakawan di layanan referensi sebaiknya Perpustakaan Universitas Negeri Padang lebih meningkatkan lagi sarana dan prasarana yang ada di layanan referensi dan lebih memperhatikan pustakawan dalam memberikan pelayanan kepada pemustakanya agar pemustaka yang berkunjung merasa nyaman dan dihargai sebagai makhluk sosial.

\section{DAFTAR PUSTAKA}

Azis, A. (2006). Pustakawan sebagai tenaga professional di bidangperpustakaan, informasi dan dokumentasi. JKDMM: JurnalKepustakawanan Dan Masyarakat Membaca, 39-50.

Berawi, I. (2012). Mengenal Lebih Dekat Perpustakaan Perguruan Tinggi. Jurnal Iqra' Volume 06 No.01, 49.

Cahyaningtyas, R., \& Iriyani, S. (2015). Perancangan Sistem Informasi Perpustakaan Pada Smp Negeri 3 Tulakan, Kecamatan Tulakan Kabupaten Pacitan. Indonesian Journal on Networking and Security, 15-20.

Effendy, O. U. (1993). Dinamika Komunikasi. Bandung: Remaja Rosda Karya.

Kalsum, U. (2016). Referensi sebagai layanan, referensi sebagai 


\section{Info Bibliotheca}

Jurnal Perpustakaan dan IImu Informasi

ISSN 2714-805X

Volume 1 Nomor 2, Juni 2020

Page : 90-98

Published by Program Studi Perpustakaan dan IImu Informasi FBS Universitas Negeri Padang, Indonesia

tempat: sebuah tinjauan

terhadap layanan referensi di

perpustakaan perguruan tinggi.

jurnal iqra, 132-146.

Pendit, P. L. (2009). Perpustakaan

Digital: Kesinambungan dan

Dinamika. Jakarta: Cita

Karyakarsa Mandiri .

Siagian, S. P. (2009). Administrasi

Pembangunan. Jakarta: Bumi Aksara.

Siregar, M. R. (2015). KOMPETENSI

YANG HARUS DI MIILIKI

SEORANG PUSTAKAWAN

(PENGELOLA

PERPUSTAAKAAN). jurnal iqra,

211-222.

Sugiyono. (2016). Metode Penelitian

Kuantitatif, Kualitatif dan $R \quad \& \quad D$.

Bandung: Alfabeta. 